\title{
Determinants of Export Organic Supply Chain Performance: Empirical Study of Fruits and Vegetables in Vietnam
}

Author(s): Hoang Nguyen, Van Kiem Pham, Thanh Tu Phan

Source: Journal of International Logistics and Trade 2021; 19(3):147-161

Published by: Jungseok Research Institute of International Logistics and Trade, Inha University

DOI: https://doi.org/10.24006/jilt.2021.19.3.147

Journal of International Logistics and Trade is an official journal published by Jungseok Research Institute of International Logistics and Trade, Inha University, Korea. JILT welcomes manuscripts that advance the practice and science of logistics, trade, and other related fields.

Frequency: Quarterly (March, June, September, December)

Stable URL: https://www.ejilt.org

Jungseok Research Institute of International Logistics and Trade is a specialized academic research institute representing Inha University and Inha Foundation in Korea. The institute aims to become a representative institute in Northeast Asia in the research of logistics and trade.

Stable URL: https://jrieng.inha.ac.kr

(C) Copyright. Jungseok Research Institute of International Logistics and Trade.

This is an Open-Access article distributed under the terms of the Creative Commons Attribution NonCommercial License (http://creativecommons.org/licenses/by-nc/4.0/) which permits unrestricted noncommercial use, distribution, and reproduction in any medium, provided the original work is properly cited 



\title{
Journal of International Logistics and Trade
}

J. Int. Logist. Trade, 2021, Vol. 19, No. 3, 147-161

pISSN : 1738-2122 eISSN : 2508-7592

https://doi.org/10.24006/jilt.2021.19.3.147

https://www.ejilt.org

\section{ARTICLE}

\section{Determinants of Export Organic Supply Chain Performance: Empirical Study of Fruits and Vegetables in Vietnam}

\author{
Hoang Nguyen ${ }^{1}$, Van Kiem Pham ${ }^{1, *}$, Thanh Tu Phan ${ }^{2}$ \\ ${ }^{1}$ Thuongmai University, Hanoi 100000, Vietnam \\ ${ }^{2}$ University of Hai Duong, Hai Duong 170000, Vietnam
}

Received June 22, 2021
Revised August 28, 2021
Accepted September 13, 2021

*Corresponding author: Van Kiem Pham
Thuongmai University, Hanoi 100000,
Vietnam
Tel: +0973661818
E-mail: kiem.pv@tmu.edu.vn

\begin{abstract}
Based on a sample of 308 enterprises, this paper studies the determinants of export organic supply chain performance. The results indicate seven positive determinants that influence positively the supply chain performance, including: (i) need-satisfying ability (NSA), (ii) relationship management, (iii) information management, (iv) quality management, (v) coordination and cooperation mechanisms, (vi) operation management, and (vii) marketing strategy of the export organic supply chain. In contrast, the differentiated segmentation strategy and cost strategy have no impact on the export organic supply chain performance.
\end{abstract}

Keywords Determinants, Supply chain performance, Export, Agricultural supply chain, Organic vegetables and fruits, Vietnam

\section{Introduction}

The export organic supply chain has attracted attention from scholars (Augustine and Guillaume, 2021; Edwardson and Santacoloma, 2013; Kerdsriseam and Suwanmaneepong, 2015; Lau et al., 2020; Pu et al., 2020; Yu and He, 2021) since the organic products have become recently favorable consumption trend in the world. If in 2000, export of organic agricultural products was only about 13.85 million U.S. dollars, accounted for an insignificant proportion of worldwide agricultural export; in 2000 , despite the global covid-19 pandemic, the organic export grew $20.85 \%$ by compared with 2019 , by attainting about 18.7 million U.S. dollars, accounted for $0.11 \%$ of worldwide export, and for $1.62 \%$ of worldwide agricultural export ${ }^{1}$.

The globalization and increasing standard of living promote the worldwide organic market, that encouraged transnational firms, retailers and importers to participate and establish organic export supply chain, in order to meet the new raising demands for organic agricultural products at a lower cost and at reasonable prices (Padel and Lampkin, 2007). A good organic export supply chain may facilitate organic agricultural producers, who are still often small-scaled, particularly the ones in developing and least developed countries, to meet strict production, processing, packaging conditions specified by organic certification schemes and regulations (Semos, 2002). For example, IFAD (2005) defined the organic farming system that must be "[...] in harmony with local environment using land husbandry techniques such as soil-conservation measures, crop rotation and the application of agronomic, biological and manual methods instead of synthetic inputs" (p.xiii). So, organic agricultural product result from an organic agricultural production or farming system " $[\ldots]$ which promotes and enhances agro-ecosystem health, including biodiversity, biological cycles, and soil biological activity" (FAO and WHO, 2007, p.2), and "[...] that sustains the health of soils, ecosystems, and people. It relies on ecological processes, biodiversity and cycles adapted to local conditions, rather than the use of inputs with adverse effects" (IFOAM, 2008).

Also, during the past two decades, emerging and developed countries (such as United Stated, China, United Kingdom, European Union, Japan ...) have raised significantly, in number and also in more stricter requirements, their non-tariff measures,

\footnotetext{
${ }^{1}$ Estimated according to the data of FiBL (Research Institute of Organic Agriculture: https://statistics.fibl.org/world/markets-trade-world. html), Organic Trade Association (https://ota.com/tradedata), and UNCTAD (United Nations Conference on Trade and Development: https://unctadstat.unctad.org/EN/Index.html).
} 
including sanitary and phytosanitary measures and technical barriers to trade. According to Marks (2019), "trade costs of nontariff measures are more than double that of ordinary customs tariffs" (p.3). Since the actual covid-19 pandemic happening in 2019, it seems that, despite the organic supply chain, these non-tariff measures continue to raise in the main markets of organic products (United Stated - 42.04\% of worldwide market share; Germany - 11.25\%; France - 10.62\%; China - 7.99\%); and they have become a key concern for organic producers and also all of other actors of the export organic supply chain (Marks, 2019; Willer et al., 2021).

In this context of strictly controlled production conditions, increasing rival competition and non-tariff measures, natural and pandemic diseases, export organic producers and supply chain actors must optimize their cooperation for minimizing and sharing risks in the overall supply chain, from suppliers, producers to final customers. For example, it should strengthen the cooperative links between distribution firms and organic produces; or the organic agricultural producers should explore the market, make strategic planning, and access the innovative resources to improve the products and upgrade their production systems (Augustine and Guillaume, 2021; Stolze and Lampkin, 2009; Worstell, 2020).

So, we think a study on determinants of the export organic supply chain performance will offer an overview for supply chain actors and also policy-makers about what to affect to improve their supply chain performance. However, there are few articles in exception of some ones of Yang (2018), Yu and $\mathrm{He}$ (2021). In the literature, we found articles focusing on successful factors of supply chain in general and agricultural one, including: strategy (Agi and Yan, 2020; Lambert and Cooper, 2000; van Roekel and Boselie, 2002;); need-satisfying ability (Albert, 2003; van Roekel and Boselie, 2002); cost reducing (He and Yin, 2020; Whicker et al., 2009); operation, relationship and quality management (Ivanov et al., 2018; Zander and Hamm, 2010); coordination and cooperation (Green et al., 2012; Mostaghel et al., 2019; Xu and Beamon, 2006). The research question is posed on what are determinants of export organic supply chain performance?

For the above reason, this study aims to apply these determinants for export organic supply chain performance, specifically in an empirical study on the organic supply chain of vegetables and fruits for export in a developing country of Vietnam. This study is structured in three sections. In the first one of literature review, by adopting the export-driven approach of organic supply chain, we will develop research hypothesis on determinants of export organic supply chain performance. The second section will present the research methodology, including the research field, data mining, variable measurement and validity. In the third section, research findings will be analyzed and discussed on the determinants of export organic supply chain performance.

\section{Literature review}

\subsection{The export-driven approach of organic supply chain}

The export-driven approach, also called market-oriented or consumer-driven approach focuses on the ability of meeting customers' demand, in this case, the increasing demand of organic agricultural products of main markets, including United States, European Union, Japan. Policy is also used as tools for developing local markets and for promoting the export of organic agricultural products (Edwardson and Santacoloma, 2013; Hauser and Delve, 2007). In fact, government can play an important role in the formation and development of export organic supply chain. The competitiveness of organic agricultural products for export may be impaired due to the lack of social infrastructure or the government's supportive policies (Padel and Lampkin, 2007).

In this export-driven approach, export organic supply chain is a process combining organic agricultural producers, processing and packaging firms, government agencies and intermediaries such as export traders, donors, development organizations (Dimitri and Oberholtzer, 2007). Its main activities, as a normal supply chain, include: input supply, production, distribution to foreign markets, and recovery of organic agricultural products. The distinguishing characteristics of export organic supply chain involve in the facts that: (i) the production, harvesting and trading of organic agricultural products are seasonal; (ii) the process and outcomes are completely friendly with the environment; (iii) the organic agricultural products as outcome of the supply chain are strongly dependent on the natural conditions; (iv) the supply chain quality directly influence the consumers' health; (v) the organic agricultural products are fresh, leading to difficulties in preserving for a long time; and (vi) the organic agricultural products must be contained at least 95\% ingredients from agriculture (Edwardson and Santacoloma, 2013; Panpluem and Yin, 2021).

In the nature, the export organic supply chain is a supply chain providing the organic agricultural products, combining organizational actors that are directly or indirectly involved in satisfaction of customer needs for organic agricultural products. Specifically, on the basis of the demand for organic agricultural products of the target markets, intermediaries make decisions 
by proposing to producers about kind of organic agricultural products, production methods and scale. Intermediaries also play a role in supporting agricultural producers to improve their knowledge and skills in organic farming through training programs on organic production methods, organic technology, etc. In an export organic supply chain, actors have strategic cooperation relationships in order to optimize the needs of the target end-consumers (Hauser and Delve, 2007); but each actor maintains its own autonomy and identity. The export organic supply chain can consist of many supply chains and business processes in parallel or sequential order over time. An actor can play different roles in different supply chains, maybe a cooperator, coordinator and/or coopetitor in other supply chains (van der Vorst et al., 2007).

In general, export is the main driver of the organic supply chain development by mainly focusing on the ability to meet the foreign customers' needs. In this model, customers from importing countries have a decisive impact; their needs and requirements determine the quantity, quality, design and type of export organic agricultural products, methods and scale of its production ..., so on how the organic agricultural industry develops (Edwardson and Santacoloma, 2013). In developing and least developed countries, such as Vietnam, Uganda and Tunisia, the organic agricultural industry aims mainly to export. But different export markets (Japan, European Union, United States) stimulate the development of organic agricultural production in different orientations. These result difficulties in expanding production scale, in diversifying organic products, in meeting different needs of customers.

\subsection{Determinants of organic supply chain performance}

In the export-driven approach, we now development research hypothesis. On the basis of the literature review on determinants of supply chain performance, we apply nine ones for export organic supply chain by establishing the research model as in the Figure 1.

\subsubsection{Differentiated segmentation strategy}

The differentiated segmentation strategy determines the selection of actors in the supply chain, in the way that these actors work together towards a specific market segment to create a sustainable competitive advantage, that allows the supply chain obtaining superior performance than competitors (Brun and Castelli, 2008; van Roekel and Boselie, 2002). For example, a trader, who exports organic products to high demand markets (such as the United States or Japan), should create sustainable linkages with the suppliers and agricultural producers for meeting the requirements of these markets. Also, supply chains tend

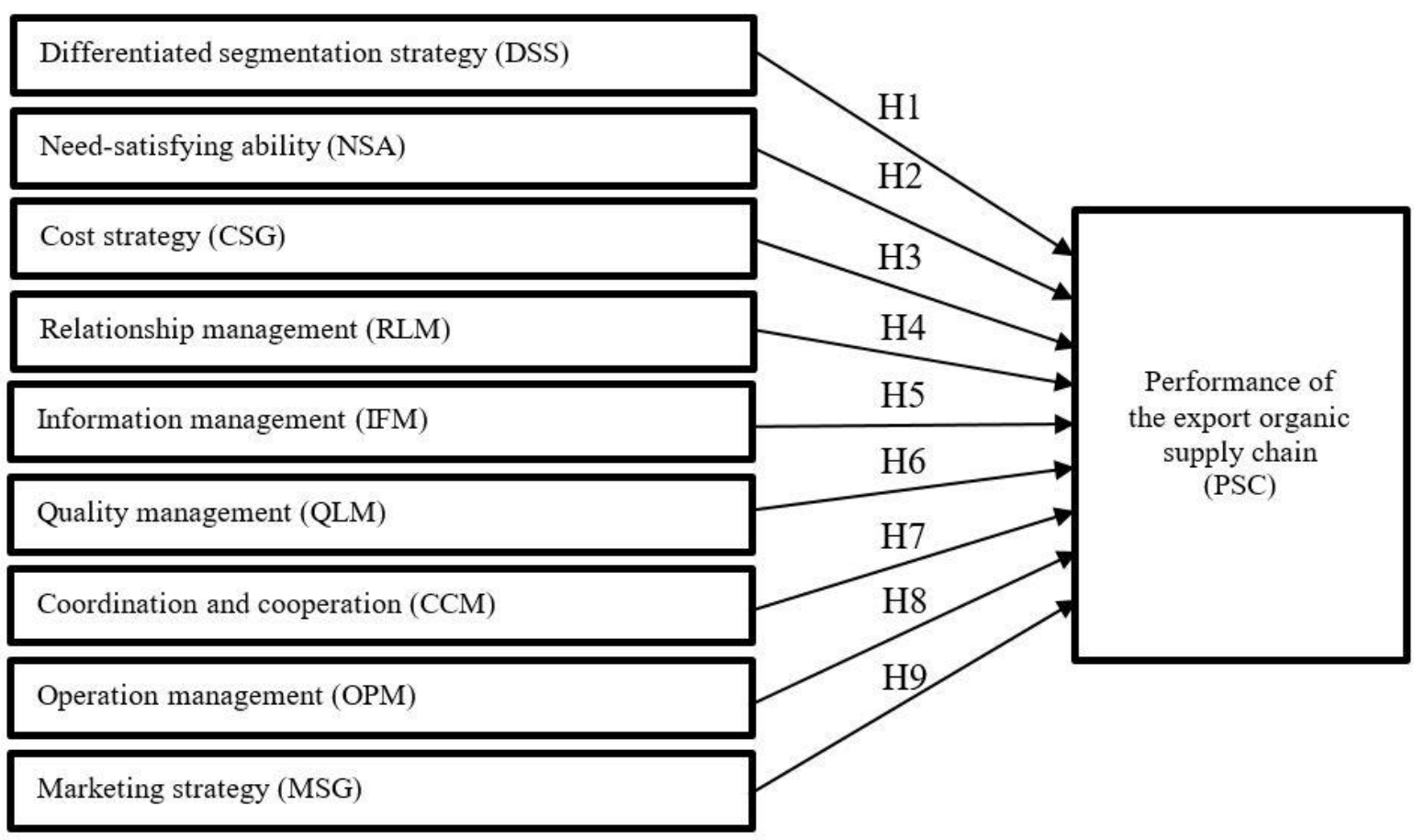

Figure 1. Research model on the determinants of organic supply chain performance. 
to select its optimal partners to get competitive prices. As a result, the organic agricultural products are of high quality and at competitive prices; these contribute to enhance the organic export supply chain performance (Agi and Yan, 2020).

Also, the differentiated segmentation strategy of the export organic supply chain focuses on product differentiation, service differentiation, and value-added demand. These require actors must have deep knowledge on customers' demand for organic agricultural products by studying, collecting and sharing continuously market information; and also, by cooperating and supporting others actors in the export organic supply chains for satisfying foreign customers. As a result, the supply chain operates more and more efficiently. Each market segment has different characteristics, so differentiated segmentation strategy requires supply chain actors to determine costs, profitability and to develop specialized products and services suitable for each segment (Agi and Yan, 2020).

Furthermore, the differentiated segmentation strategy allows finding suitable actors to optimize the export organic supply chain. These actors (including: suppliers, producers, transporters, exporters, logistics firms, etc.) contribute to increase competitive advantage and lower prices of organic agricultural products by minimizing the activity costs in the chain. This contributes to increasing profitability and enhancing the sustainability of the chain. In this perspective, we propose the first hypothesis:

\section{H1: The differentiated segmentation strategy is positively associated with the performance of export organic supply chain.}

\subsubsection{Need-satisfying ability}

Van Roekel and Boselie (2002) argue that need-satisfying ability is one of the key factors influencing the sustainability and performance of the agricultural supply chain. So, the export organic supply chains need to meet the customers' needs related to quality, safety, sustainability, health, and animal welfare. All these dimensions of organic agricultural product play important role in the customer satisfaction and the competitiveness of its supply chains.

In practice, customers are always willing to pay higher prices for high quality and environmentally friendly products. As the export organic supply chains focuses on the ability to meet demand, the quality standards on the basis of training, supporting producers, and also strictly controlling the entire chain activities according to the requirements specified by organic certification schemes and regulations. Also, concern for consumer health promotes the sustainability and performance of the supply chain as many consumers are now interested in environmental protection and animal welfare when choosing food.

As a result, the export organic supply chain performance increases when all actors join together to meet the needs of the target customers. So, the need-satisfying ability of the export organic supply chain enhances its performance by influencing the actors' ability to respond to the customer needs (Albert, 2003). The need-satisfying ability requires actors to strive to provide the requested organic agricultural products in the export market; at the same time, all the chain actors cooperate continuously to improve customer confidence for the reputation and brands of the organic agricultural products. In this logic, we propose the following hypothesis:

\section{H2: The need-satisfying ability is positively associated with the performance of export organic supply chain.}

\subsubsection{Cost strategy}

A competitive pricing strategy promotes the development and enhances the performance of export organic supply chains. The competitive pricing strategy of the export organic supply chains focuses on giving the appropriate price - quality correlation of products and services. Also, this strategy aims to achieve optimal price for target market on the basis of optimal cost strategy of the supply chain (He and Yin, 2020; Whicker et al., 2009).

Specifically, to carry out all stages from production, transportation to export of organic agricultural products, supply chain actors will bear the costs that are directly involved in the cost of organic agricultural products. Therefore, in order to have reasonable price, as well as the competitiveness of organic agricultural products in the international market, actors are forced to minimize the individual and global costs of the export organic supply chain.

So, agricultural supply chain adjusts their operations and minimize the costs by reducing transaction costs to optimize chain results (van Roekel and Boselie, 2002). Thus, building a good cost strategy can contribute to developing the export organic supply chain by improving the supply chain performance. According to these arguments above, we hypothesize that:

\section{H3: The cost strategy is positively associated with the performance of export organic supply chain.}




\subsubsection{Supply chain relationship management}

In the nature, management of export organic supply chain consist in managing the cooperative relationship among chain actors. In fact, the traditional methods of exchanging goods have become outdated, and therefore a creative new method is required. In which, each actor in the supply chain contributes his best capabilities in the consumption of organic agricultural products. Also, each actor takes responsibility for three different areas, including: (i) supplying the required materials and raw materials, ensuring quality standards and on-time delivery; (ii) participating in goods distribution management and (iii) cooperating with customers to find solutions to minimize production costs. For the success of supply chain relationship management, actors need to have a joint plan and control of products, technologies and investments from production to export; at the same time cooperate based on interdependence and trust between supply chain actors (Fynes et al., 2005; Prajogo and Olhager, 2012). In addition, each actor should develop good relationship with before and after one in the export organic supply chain.

The relationships in the export organic supply chains are established and developed on the basis of mutual trust and combined advantages jointly exploited of chain actors. This allows them to use resources properly and to have more opportunities to bring organic agricultural products to customers. The supply chain relationship management allows chain actors to strongly reduce costs, and increase the supply chain performance. Ensuring benefits of chain actors determines the sustainability of the relationship management of the organic supply chain of exporting agricultural products.

In general, the relationship management is one of the most important contents of the export organic supply chain. In particular, the trust of supply chain actors is decisive to building a sustainable supply chain of organic agricultural products, thereby positively impacting the performance of the supply chain. Ineffective relationship management causes all other systems (information systems, inventory, contracts, etc.) and the entire chain to fail. So, we propose the following hypothesis:

\section{H4: The supply chain relationship management is positively associated with the performance of export organic supply chain.}

\subsubsection{Supply chain information management}

Information sharing among chain actors facilitates integration, so improve the supply chain performance (Prajogo and Olhager, 2012). The accuracy of information determines the overall performance of the chain, from raw material supply to the ability to reach the end customer. Without computer and information systems such as Electronic Data Interchange (EDI), JustIn-Time (JIT), e-commerce, etc., the supply chain of organic agricultural products for export will have to face many difficulties. Sharing information in the supply chain allows chain actors to reduce costs by quickly capturing and updating trends (Albert, 2003).

In general, supply chain information management focuses on sharing totally information among actors, as well as sharing information for decreasing the business cycle. In order to effectively manage information, the export organic supply chains should promote sharing information for controlling and sharing costs among actors; and sharing information for capturing customer demand and trends.

Prajogo and Olhager (2012) demonstrates that sharing totally information among actors is considered as an important factor affecting the performance of the supply chain. A lack of information can change the value of the entire export organic supply chain by not keeping up with market trends. On the market today, many software firms provide software and management programs to help the supply chain in general and the supply chain of organic agricultural products for export in particular. However, the core of the ability to exchange information flows remains trust among the chain actors. Without trust among chain actors, assistive information technologies cannot promote their effectiveness in linking actors. According to these arguments above, we propose the following hypothesis:

\section{H5: The supply chain information management is positively associated with the performance of export organic supply chain.}

\subsubsection{Supply chain quality management}

Supply chain quality management is very important to the long-term competitiveness of the export organic supply chain. Robinson and Malhotra (2005) defined the quality management of the supply chain as formal coordination and integration of business processes involving all organizations as actors to each other in the supply channel to measure, analyze, and continually improve products and processes for creating value and achieving intermediate and end customer satisfaction in the marketplace. 
Lo and Yeung (2006), in their research on quality management in the supply chain, pointed out ten important factors that form a supply quality management system. These factors are categorized into three main groups (i) supplier selection, (ii) supplier development and (iii) supplier integration. The quality management contents in the supply chain include: customer focus, quality practice, supplier relationships, leadership, HR practice, business results, and safety.

So, for managing export organic supply chain, actors should focus on joint plan and joint control of agricultural product quality; as well as filtering fit actors with necessary competences. Controlling the quality of products - services of actors is also very important to the export organic supply chain. Also, supply chain needs to improve the quality of products - services of each actor and the ones of the entire export organic supply chain.

The relationship between the quality management and the export organic supply chain performance has been studied and it was found that the performance of the supply chain can be enhanced by improving the supply chain quality management (ChuHua et al., 2001). Improving the quality of all processes in the export organic supply chain allows reducing costs and improving the performance of resource utilization and processes. On the whole, quality management of the export organic supply chain is a system-based approach for improving the performance of the entire supply chain. According to these arguments above, we hypothesize that:

\section{H6: The supply chain quality management is positively associated with the performance of export organic supply chain.}

\subsubsection{Supply chain coordination and cooperation mechanisms}

An export organic supply chain consists of many interdependent actors. So, coordination and cooperation among them present as strategic reactions to the problems arising from the dependence of the actors in the chain, thereby ensuring chain performance. Coordination and cooperation mechanism is a set of methods used to manage interdependencies among actors (Mostaghel et al., 2019). With the growing importance of high-performance organic agricultural supplies and the advantages gained through supply chain coordination for export organic agricultural products, the challenge for organizations is to figure out how to choose the right coordination and cooperation mechanism to manage interdependencies among organizations. Xu and Beamon (2006) develop a systematic process, which is based on attributes to choose coordination and cooperation mechanisms in the supply chain. In essence, the coordination and cooperation mechanisms among chain actors is the interaction of different individuals, entities and processes to realize the export organic supply chain's goals. Consequently, the coordination and cooperation mechanisms provide tools to effectively manage these interactions.

Coordination and cooperation mechanisms of the export organic supply chain can be distinguished based on four attributes, namely: (i) resource sharing structure, (ii) make decision method, (iii) control level and (iv) sharing of risks or benefits. Due to the fact that the selection of a coordination mechanism in the export organic supply chain is often based on cost reduction, three types of costs should be considered in coordination and cooperation, including: coordination costs, operational risk costs and opportunity risk costs.

Building a coordination and cooperation mechanism in the supply chain consists in developing a framework that allows actors to choose an appropriate mechanism, based on costs and characteristics of their specific operating environment (Mostaghel et al., 2019; Xu and Beamon, 2006). So, as to build an effective coordination and cooperation mechanism, export organic supply chains should establish mechanisms that fit its characteristics as we discussed in the section 1.1. Utmost attention should be paid to mechanism for sharing resources and decision-making. In addition, making a coordination mechanism in the export organic supply chain is also concerned with the method and extent of control, as well as method of sharing risks/benefits. From which, the coordination and cooperation mechanisms in the export organic supply chain make an important contribution to improving its performance. In this perspective, the seventh research hypothesis is formulated as following:

\section{H7: The coordination and cooperation mechanisms are positively associated with the performance of export organic supply chain.}

\subsubsection{Supply chain operation management}

Operation management in the supply chain involves managing the resources to produce and distribute organic agricultural products (Ivanov et al., 2018). Operation management in the export organic supply chain focuses on cost, time, quality and resilience. This activity requires multi-disciplinary knowledge, from business administration, optimization, engineering to information systems. Operation management in the export organic supply chain includes: logistics, warehouse management, shipping optimization, procurement quantity optimization, inventory management, cross-connect design, intermodal terminal 
design....

In the literature, some operation management measures for the export organic supply chain have been developed. Typically, the efficient consumer response model (ECR) is designed to increase the consumer orientation and the cost-effectiveness of the commodity supply chain in general and organic agricultural products in particular. By adopting the ECR model, the supply actors should implement new management systems to improve logistics and increase the use of information technologies as well as strengthen the management of organic product quality (Lambert and Cooper, 2000).

Furthermore, in order to guarantee the quality of export organic agricultural products, the chain actors have developed "integrated chain care" tools, such as social responsibility, good agricultural practices (GAP), total quality management and Hazard Analysis Critical Control Point (HACCP). The implementation of these tools throughout the cross-border supply chain allows chain actors to guarantee the quality and safety of organic agricultural exports and ensure that the social supply chain is also accepted (Zander and Hamm, 2010). For the parties involved in product purchase and distribution and B2B customers, these companies can require suppliers and manufacturers to comply with standards related to export organic agricultural raw materials or products having specific origin and safety parameters. To develop supply processes, purchasing companies can participate in and contribute to suppliers' internal environmental initiatives. In logistics operations, suppliers can use distribution network arrangements to improve the performance of shipping export organic agricultural products. Not only that, purchasing and distributing enterprises should also develop good relationships with suppliers. This will not only allow improving production performance, reducing supply/sales risks, but also contributing to successfully addressing environmental/social issues.

Suitable operation management of the supply chain offer advantages for actors, such as: reducing product loss in transportation and storage; increasing profits; improving technology, advanced techniques, capital and knowledge among the chain actors; better information about product flows, market and technology; better control of the safety and quality of organic agricultural products; sharing of large investments and risks among chain partners.... (Ivanov et al., 2018; Lambert and Cooper, 2000; Zander and Hamm, 2010) So, we think also that operation management of the organic supply chain may influence positively the export organic supply chain performance. We propose the eighth hypothesis:

\section{H8: The supply chain operation management is positively associated with the performance of export organic supply chain.}

\subsubsection{Supply chain marketing strategy}

The export-driven approach, marketing strategy plays an important role in the export organic supply chain functioning, that must be consistent with the general marketing communication strategies of chain actors. This strategy provides necessary information by building relationships among actors, that improve the supply chain performance. Essentially, a marketing strategy establishes an environment in which all actors interact and participate in business development programs, contributing to improving customer service and the performance of the supply chain (Lambert and Cooper, 2000).

The main goal of organic supply chain marketing strategy is to increase the satisfaction of customers in export markets. The marketing strategy, once improved, will enable chain actors to provide information in time for each other and for customers, contributing to the sustainability and the performance of the supply chain (Green et al., 2012). When supply chain partners have the right level of market awareness, they can add value and take an active role in supplying export organic agricultural products. Marketing can be designed through programs to help partners develop their own business and make it easier for supply chain actors to work together. The main content of the supply chain's marketing strategy focuses on Marketing mix, promotion campaigns, and communication campaigns. Further, branding of agricultural products and branding of the supply chain should also be attached importance to by export organic supply chains to improve the performance of the supply chain (Agi and Yan, 2020).

In general, supply chain marketing strategy enable all of actors to focus on customers other than production activities. By improving communication, support and collaboration, marketing strategies can contribute to improving the performance and competitive advantages of export organic supply chain. According to these arguments, we formulate the nineth hypothesis:

H9: The marketing strategy is positively associated with the performance of export organic supply chain.

\section{Research methodology}

\subsection{Research field}

For testing the research hypotheses, our empirical study explores the organic supply chains for fruit and vegetable export 
from Vietnam. In recent years, Vietnam agriculture has continued to be developed; during the period 2011-2016, the export value of Vietnam agricultural products achieved an average growth rate of 12.7\%/year. By profiting favorable natural conditions for agricultural production, Vietnamese firms focus on investing in high-tech agriculture for high-quality supply chains in meeting needs and requirements of export markets.

Actually, 45/63 provinces of Vietnam have successfully established 382 organic agro-forestry-fishery supply chains, with the main products of vegetables, fruits, tea, meat, eggs, rice and seafood. Of which, 92 export supply chains of organic vegetables and fruits, mainly located in Hanoi Capital, Hoa Binh Province, Lao Cai Province, Ha Giang Province, Ha Nam Province, Lam Dong Province, Ca Mau Province, Ben Tre Province and Ba Ria-Vung Tau Province, are determined as research objects of this study. These organic vegetables and fruits aim mainly to export to the European, American and Japanese markets.

In the organic supply chains of fruit and vegetable in Vietnam, farmers are the main producers who distribute products to other actors in the supply chain. However, they are often small-scale producers, only a few of them who participate in specialized cultivation know the technical requirements of growing safe vegetables, the rest with limited knowledge.

\subsection{Data mining}

For collecting data, we implemented a survey on actors of export supply chain of organic tea and vegetable in Vietnam. More than 350 questionnaires were distributed to the actors of 92 export organic vegetable and fruit supply chains certified by the Ministry of Industry and Trade of Vietnam.

The returned questionnaires are then processed and entered in SPSS. By eliminating some invalid ones because of lack of important information, the final 308 valid questionnaires, representing 308 actors of 92 export organic vegetable and fruit supply chains in Vietnam, constituted our research sample (Figure 2).

In our research sample, the majority of the supply chain actors have experience in their actual business field and have a great reputation on the market (over $50 \%$ of firms operating over 5 years). They are mainly joint stock companies (31.5\%), companies limited (21.4\%), and family households (23.7\%). 32.5\% of the actors are large-scale firms, with an average annual turnover of VND 100-500 billion. Most of the firms are small and medium enterprises (from 100-299 employees).

\subsection{Variable measurement and validity}

\subsubsection{Measurement of independent variables}

On the basis of literature review, we developed the measurement of independent variables as in theTable 1 .

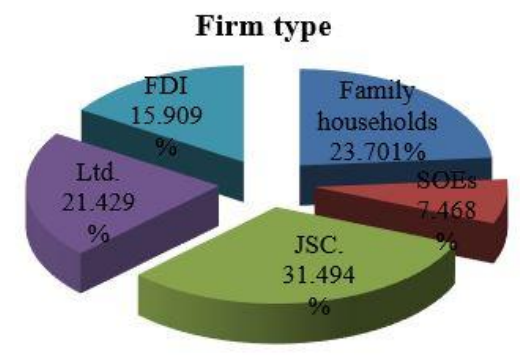

Time in SC
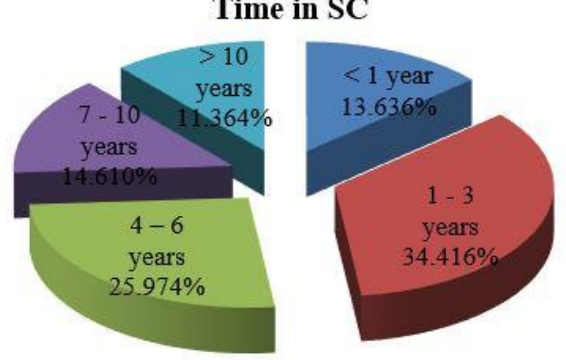

Employees

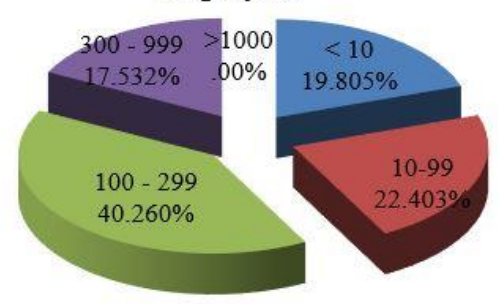

Turnover

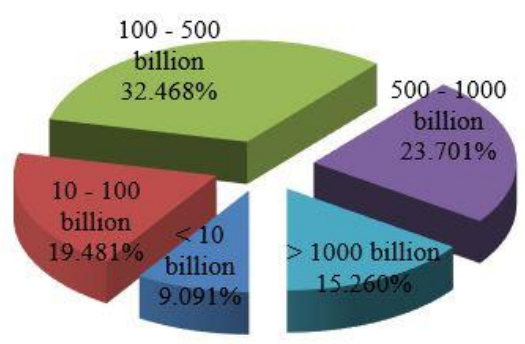

Figure 2. Research sample. 
Table 1. Measurement of independent variables

\begin{tabular}{|c|c|c|c|c|}
\hline No. & Variable & Variable name & Items & Reference \\
\hline 1 & $\begin{array}{l}\text { Differentiated } \\
\text { segmentation strategy } \\
\text { of the organic supply } \\
\text { chain }\end{array}$ & DSS & $\begin{array}{l}\text { - Product differentiation (DSS1) } \\
\text { - Service differentiation (DSS2) } \\
\text { - Value-added demand (DSS3) }\end{array}$ & $\begin{array}{l}\text { van Roekel and } \\
\text { Boselie (2002); } \\
\text { Brun and Castelli } \\
\text { (2008); Agi and } \\
\text { Yan (2020) }\end{array}$ \\
\hline 2 & $\begin{array}{l}\text { Need-satisfying ability } \\
\text { of the organic supply } \\
\text { chain }\end{array}$ & NSA & $\begin{array}{l}\text { - Quality (NSA1) } \\
\text { - Safety (NSA2) } \\
\text { - Sustainability (NSA3) } \\
\text { - Health (NSA4) } \\
\text { - Animal Welfare (NSA5) }\end{array}$ & $\begin{array}{l}\text { van Roekel and } \\
\text { Boselie (2002); } \\
\text { Albert (2003) }\end{array}$ \\
\hline 3 & $\begin{array}{l}\text { Cost strategy of the } \\
\text { organic supply chain }\end{array}$ & CSG & $\begin{array}{l}\text { - Price - quality of products - services (CSG1) } \\
\text { - Optimal price for target export market (CSG2) } \\
\text { - Optimal costs for actors of the supply chain (CSG3) } \\
\text { - Competitive price in comparing with the one of competitors (CSG4) }\end{array}$ & $\begin{array}{l}\text { van Roekel and } \\
\text { Boselie (2002); } \\
\text { Whicker et al. } \\
\text { (2009); He and Yin } \\
\text { (2020) }\end{array}$ \\
\hline 4 & $\begin{array}{l}\text { Supply chain } \\
\text { relationship } \\
\text { management }\end{array}$ & RLM & $\begin{array}{l}\text { - Joint plan and control of products, technologies and investments } \\
\text { from production to export (RLM1) } \\
\text { - Cooperation based on interdependence and trust between supply } \\
\text { chain actors (RLM2) } \\
\text { - Each actor develops good relationship with before and after actors } \\
\text { in the supply chain (RLM3) }\end{array}$ & $\begin{array}{l}\text { Fynes et al. (2005); } \\
\text { Prajogo and } \\
\text { Olhager (2012) }\end{array}$ \\
\hline 5 & $\begin{array}{l}\text { Supply chain } \\
\text { information } \\
\text { management }\end{array}$ & IFM & $\begin{array}{l}\text { - Sharing totally information among actors (IFM1) } \\
\text { - Sharing information for decreasing the business cycle (IFM2) } \\
\text { - Sharing information for controlling and sharing costs among actors } \\
\text { (IFM3) } \\
\text { - Sharing information for capturing customer demand and trends } \\
\text { (IFM4) }\end{array}$ & $\begin{array}{l}\text { van Roekel and } \\
\text { Boselie (2002); } \\
\text { Albert (2003); } \\
\text { Prajogo and } \\
\text { Olhager (2012) }\end{array}$ \\
\hline 6 & $\begin{array}{l}\text { Supply chain quality } \\
\text { management }\end{array}$ & QLM & $\begin{array}{l}\text { - Joint plan and joint control of product quality (QLM1) } \\
\text { - Filtering fit actors with necessary competences (QLM2) } \\
\text { - Controlling the quality of products - services of actors (QLM3) } \\
\text { - Improving the quality of products - services of each actor and the } \\
\text { ones of the whole supply chain (QLM4) }\end{array}$ & $\begin{array}{l}\text { Robinson and } \\
\text { Malhotra (2005); } \\
\text { Chu-Hua et al. } \\
\text { (2001); Lo and } \\
\text { Yeung (2006) }\end{array}$ \\
\hline 7 & $\begin{array}{l}\text { Supply chain } \\
\text { coordination and } \\
\text { cooperation } \\
\text { mechanisms }\end{array}$ & $\mathrm{CCM}$ & $\begin{array}{l}\text { - Mechanisms that fit the supply chain's characteristics (CCM1) } \\
\text { - Mechanisms of sharing resources (CCM2) } \\
\text { - Mechanisms of decision-making (CCM3) } \\
\text { - Method and extent of control (CCM4) } \\
\text { - Method of sharing risks / benefits (CCM5) }\end{array}$ & $\begin{array}{l}\text { Xu and Beamon } \\
(2006) ; \text { Mostaghel } \\
\text { et al. (2019) }\end{array}$ \\
\hline 8 & $\begin{array}{l}\text { Operation management } \\
\text { of the organic supply } \\
\text { chain }\end{array}$ & OPM & $\begin{array}{l}\text { - Managing operations of supplying inputs (OPM1) } \\
\text { - Managing operations of cropping products (OPM2) } \\
\text { - Managing distribution and sale operations (OPM3) } \\
\text { - Managing after-sales operations (OPM4) }\end{array}$ & $\begin{array}{l}\text { Ivanov et al. (2018); } \\
\text { Lambert and } \\
\text { Cooper (2000); } \\
\text { Zander and Hamm } \\
\text { (2010) }\end{array}$ \\
\hline 9 & $\begin{array}{l}\text { Marketing strategy of } \\
\text { the organic supply } \\
\text { chain }\end{array}$ & MSG & $\begin{array}{l}\text { - Marketing mix (MSG1) } \\
\text { - Promotion campaigns (MSG2) } \\
\text { - Communication campaigns (MSG3) } \\
\text { - Branding of agricultural products (MSG4) } \\
\text { - Branding of the supply chain (MSG5) }\end{array}$ & $\begin{array}{l}\text { Lambert and Cooper } \\
\text { (2000); Green et al. } \\
\text { (2012); Agi and } \\
\text { Yan (2020) }\end{array}$ \\
\hline
\end{tabular}

\subsubsection{Measurement of dependent variable}

The performance of the export organic supply chain (PSC) is dependent variable, that is assessed by three criteria according to Koekoek et al. (2010), including:

- Strategic fit implies that the export strategy must match the mission and strategic objectives of the organic supply chain. In which the suitability of the market strategy or the final customer need plays an especially important role (PSC1). At the same time, the supply chain should exist and operate in line with the criteria and perspectives of the chain actors (PSC2). 
- Financial criteria of costs and benefits (PSC3): Profitability is the raison-d'être of any export organic supply chain. This is estimated by comparing all the costs and benefits generated from supply chain activities.

- Ethical factors (PSC4): Organic agricultural products are sustainable, friendly to people and the environment, not only in the final products but also in the input materials and the entire production, supply and distribution processes. Organic agriculture is considered by supply chain actors as a high-end production system, with little impact on the environment, positively contributing to biodiversity and being more accountable to producers and workers.

\subsubsection{Variable measurement and validity}

We conducted confirmatory factor analysis (CFA) with each variable. The CFA results in the Table 2 indicate that Cronbach's Alpha of all scales or independent and dependent variables are greater than 0.7 ; so, the variable measurement is validated. Therefore, all variables are accepted and could be used in the regression analysis.

\section{Research findings}

The linear regression results are obtained in the Table 3.

The regression results indicate the impact of determinants on the export organic supply chain performance, in the case study of Vietnam fruit and vegetable products, as follows.

\subsection{Impact of the differentiated segmentation strategy}

According to the regression results, the differentiated segmentation strategy (variable namely DSS in Table 3) does not have significant impact on the export organic supply chain performance $(B=0.048$; Sig. $=0.092)$. So, the hypothesis 1 is invalid. We believe that differentiation segmentation is the most difficult problem facing the export organic agricultural chains of developing countries. In Vietnam, organic vegetables and fruits of organic agricultural chains are of high quality, different from ordinary vegetables and fruits of the same type. However, most organic products are produced in foreign cooperation projects or by private firms according to different standards, for example: 94.9 ha of vegetables meet the Participatory Guarantee System - PGS; 4,070.1 ha of organic tea, rice, vegetables, fruits are suitable to standards of European Union, United States Department of Agriculture (USDA), and Japanese Agricultural Standards (JAS). Thus, export organic supply chains from Vietnam aim mainly to meet the standards of their target markets; they are inactive in segmentizing the markets.

\subsection{Impact of the need-satisfying ability}

According to the regression results, the need-satisfying ability (variable namely NSA in Table 3 ) of the export organic supply chain has a significant and positive impact on the supply chain performance at confidence level of $99 \%$ with B-value $=0.353$; Sig. $=0.000$. Thus, the hypothesis 2 is validated. The better need-satisfying ability, the higher export organic supply chain performance; that is similar finding with Agi and Yan (2020), Brun and Castelli (2008) and van Roekel and Boselie (2002).

Table 2. Variable measurement and validity

\begin{tabular}{|c|c|c|c|c|c|c|}
\hline \multirow{2}{*}{ No } & \multirow{2}{*}{ Variable } & \multirow{2}{*}{ Items } & \multirow{2}{*}{ Cronbach's alpha } & \multicolumn{2}{|c|}{ KMO and Bartlett's test } & \multirow{2}{*}{$\begin{array}{c}\text { Cumulative } \\
(\%)\end{array}$} \\
\hline & & & & KMO & Sig. & \\
\hline 1 & Differentiated segmentation strategy (DSS) & 3 & 0.832 & 0.721 & 0.000 & 75.060 \\
\hline 2 & Need-satisfying ability (NSA) & 5 & 0.885 & 0.841 & 0.000 & 68.734 \\
\hline 3 & Cost strategy (CSG) & 4 & 0.889 & 0.835 & 0.000 & 75.673 \\
\hline 4 & Supply chain relationship management (RLM) & 4 & 0.893 & 0.771 & 0.000 & 76.585 \\
\hline 5 & Supply chain information management (IFM) & 4 & 0.889 & 0.824 & 0.000 & 75.302 \\
\hline 6 & Supply chain quality management (QLM) & 4 & 0.789 & 0.726 & 0.000 & 61.387 \\
\hline 7 & Coordination and cooperation mechanisms (CCM) & 5 & 0.868 & 0.800 & 0.000 & 65.799 \\
\hline 8 & Operation management (OPM) & 4 & 0.846 & 0.795 & 0.000 & 68.703 \\
\hline 9 & Marketing strategy (MSG) & 5 & 0.863 & 0.755 & 0.000 & 65.088 \\
\hline 10 & Performance of organic supply chain (PSC) & 4 & 0.880 & 0.780 & 0.000 & 73.516 \\
\hline
\end{tabular}


Table 3. Regression results

\begin{tabular}{|c|c|c|c|c|c|c|}
\hline \multirow{2}{*}{ Independent variable } & \multicolumn{2}{|c|}{ Unstandardized coefficients } & \multirow{2}{*}{$t$-value } & \multirow{2}{*}{ Sig. } & \multicolumn{2}{|c|}{ Collinearity statistics } \\
\hline & B & Std. error & & & Tolerance & VIF \\
\hline (Constant) & $0.000^{* * *}$ & 0.027 & 0.000 & 1.000 & & \\
\hline DSS & 0.048 & 0.028 & 1.693 & 0.092 & 0.947 & 1.056 \\
\hline NSA & $0.353^{* * *}$ & 0.037 & 9.641 & 0.000 & 0.562 & 1.778 \\
\hline CSG & 0.025 & 0.028 & 0.885 & 0.377 & 0.955 & 1.047 \\
\hline RLM & $0.068^{*}$ & 0.029 & 2.360 & 0.019 & 0.905 & 1.104 \\
\hline IFM & $0.195^{* * *}$ & 0.035 & 5.526 & 0.000 & 0.604 & 1.657 \\
\hline QLM & $0.077^{* *}$ & 0.028 & 2.712 & 0.007 & 0.941 & 1.063 \\
\hline $\mathrm{CCM}$ & $0.262^{* * *}$ & 0.037 & 7.013 & 0.000 & 0.541 & 1.849 \\
\hline OPM & $0.205^{* * *}$ & 0.033 & 6.233 & 0.000 & 0.697 & 1.434 \\
\hline MSG & $0.136^{* * *}$ & 0.032 & 4.217 & 0.000 & 0.720 & 1.388 \\
\hline
\end{tabular}

${ }^{*} p<0.05,{ }^{* *} p<0.01,{ }^{* * * *} p<0.001$.

VIF, variance inflation factor; DSS, differentiated segmentation strategy; NSA, need-satisfying ability; CSG, cost strategy; RLM, relationship management; IFM, information management; QLM, quality management; CCM, coordination and cooperation; OPM, operation management; MSG, marketing strategy.

Currently, export organic fruit and vegetable supply chains in developing countries like Vietnam have gradually attached importance to meeting the needs of customers in the aspects of quality, safety, sustainability, healthy and animal welfare. Organic vegetables and fruits of the export supply chain are increasingly meeting the needs for quality of end-users, ensuring the sustainability of the environment. In Vietnam, export organic vegetable and fruit farming are considered as a production method that farm management and farm environment are like a single system. Both traditional and scientific knowledge is used in export organic supply chains to increase their ability to respond to customer needs. Export organic vegetable farming focuses on the use of local natural resources and ecosystem management rather than external investments such as mineral fertilizers and agrochemicals. Synthetic chemicals and genetically modified crops are not used in growing organic vegetables and fruits for export. Vietnam's export organic fruit and vegetable supply chains cultivate without using herbicides and insecticides like in traditional agriculture.

\subsection{Impact of the cost strategy}

The regression results show that the cost strategy (variable namely CSG in Table 3) does not influence the export organic supply chain performance $(\mathrm{B}$-value $=0.025$; Sig. $=0.377$ ). Thus, we cannot validate the hypothesis 3 . In fact, the cost strategy, that relate to the product pricing, of Vietnam export organic fruit and vegetable supply chains seems to be suitable among the chain actors. The association of supply chain actors enables the chain to minimize unnecessary costs, thereby bringing higher profits. However, actually, the price of Vietnam's organic vegetables and fruits is still high in the marketplace; because, in order to produce a certified organic product, the Vietnam producers have to spend many costs to ensure the product is completely "clean" for meeting the requirements of organic certification schemes and regulations.

In fact, while the clean food can be construed as food that guarantees the permissible level of safety for consumers, organic food requires a much more rigorous process. No use of chemicals means no pesticides, and traditional manual methods for weeding are mainly used. Labor costs are therefore also increased. In addition, the fertilizer is usually manure and compost, which costs more to transport than conventional chemicals and fertilizers. These explain why we found no relationship between the cost strategy and performance of the export organic fruit and vegetable supply chain in Vietnam.

\subsection{Impact of the supply chain relationship management}

The regression results indicate that this variable RLM has a significant and positive impact on the export organic supply chain performance at confidence level of $95 \%$ with B-value $=0.068$; Sig. $=0.019$ in Table 3. Thus, the hypothesis 4 is valid. The more efficient the supply chain relationship management, the higher the export organic supply chain performance. This result is consistent with the findings of previous researches (Fynes et al., 2005; Prajogo and Olhager, 2012).

In facts, in developing countries like Vietnam, the chain actors have jointly planned to control goods, information, technology 
and capital from production to export, from raw material supply to sales to the end consumer and vice versa. Different actors joining the export organic supply chain have gradually built trust with the rest of the chain, which is reflected in the ever growth in both quantity and scale of export organic agricultural products. In the recent years, supply chain actors have actively expanded distribution co-operation with many other partners contributing to expanding the consumption network of organic agricultural products in general and fruit and vegetable products in particular. By these efforts, they have gained positive results, such as meeting more export market demand; revenue and profits in general have increased.

According to Vietnam Logistics Business Association (VLA), there are currently more than 800 firms in the supply chains of import and export organic vegetables and fruits, and this number is still growing. These firms mainly act as agents to collect goods and issue bills of lading only. Established later than foreign enterprises, Vietnamese firms lack experience in the association with farmers, households as well as organic tea, vegetables and fruits. This substantially limits the performance of co-operation between the actors in the export vegetable and fruit supply chain. In general, the export organic fruit and vegetable supply chains in Vietnam have somewhat shortened the production and distribution cycle and caught up faster with the changing trend of the market. As such, it can be affirmed that the relationship management has a significant and positive impact on the export organic supply chain performance in Vietnam.

\subsection{Impact of the supply chain information management}

The regression results indicate that this variable IFM has a significant and positive impact on the export organic supply chain performance at confidence level of $99 \%$ (with B-value $=0.195$; Sig. $=0.000$ in Table 3), by validating the hypothesis 5 . The better the supply chain information management, the higher the export organic supply chain performance. This finding is the same suitable with the one of Albert (2003) and Prajogo and Olhager (2012) concerning the positive relationship between information management and the export organic supply chain performance.

Currently, actors in Vietnam export organic supply chain have paid attention to the information management. By sharing information, they together join, plan and build trust and association for the whole chain. In addition, the information communication technology, the linkage between the chain actors is also increasingly upgraded. They furnish information for a focal point for common data integration. This common data is provided for the chain actors on the basis of applying information technology or using traditional information sharing channels such as reports, face-to-face meetings, phone calls... By implementing and applying the customer information management system, the chain actors maintain a good relationship with customers, mainly in providing products and services to well satisfy the needs of customers. This, at the same time, will enable firms to manage customer information in a centralized way and keep track of customers with related problems. Through this system, the chain actors can join in the database of their choice, from which to publish data about their products the parties, at the same time request and receive data about products from other actors. With this development, information can be made public, verified, thereby reducing the inaccuracy of the information provided and improving the mutual trust among chain actors.

\subsection{Impact of the supply chain quality management}

Our regression results show that the quality management (variable namely QLM in Table 3) has a significant and positive impact on the performance of the export organic fruit and vegetable supply chain at confidence level of $99 \%$ with B-value = 0.077 ; Sig. $=0.007$. So, the hypothesis 6 is validated. The more effective the supply chain quality management, the higher the performance of the export organic fruit and vegetable supply chain. Some researchers also provide similar findings with the ones of previous studies (Chu-Hua et al., 2001; Lo and Yeung, 2006; Robinson and Malhotra, 2005).

According to the latest agricultural supply chain report of the World Bank (WB) on Vietnam's agricultural sector, on a 100point scale, Vietnam currently scores 55.7 in supply operations, 60.6 points in product quality management, and 48.4 points in agribusiness. Compared to the Philippines, Vietnam excels in quality management but is inferior in terms of supply chain operations and trade. We can see that in the quality management of the export organic fruit and vegetable supply chains in Vietnam has focused on the formal coordination and the integration of the business processes related to all organizations as the partners in the supply chains of the export organic vegetables and fruits. So, these chains can measure, analyze and continually improve their products and processes to create value and achieve the satisfaction of intermediate and end customers in the markets. 


\subsection{Impact of the supply chain coordination and cooperation mechanisms}

This variable CCM, according to the regression results in Table 3, influences significantly and positively the performance of the export organic fruit and vegetable supply chain at confidence level of $99 \%$ (with B-value $=0.262$; Sig. $=0.000$ ), by validating the hypothesis 7 . So, the more effective the supply chain coordination and cooperation mechanisms, the higher the performance of the export organic fruit and vegetable supply chain. This finding supports the previous research such as Mostaghel et al. (2019) and Xu and Beamon (2006).

In fact, the supply chain model of export organic fruit and vegetable in Vietnam has been recently established on the basis of strongly increasing demand of export markets; and the supply chain coordination and cooperation mechanisms have still been gradually built. So, the actors are just confined to jointly researching, developing in a gradual and prudent manner. In general, the coordination and cooperation among the actors in Vietnam export organic supply chain is increasingly better; a typical example is the supply chain of export fruits in the Mekong River Delta. The Mekong Delta is the main tropical fruit production region in Vietnam due to its rich variety and suitability in natural conditions. However, the volume of exported fruits of the Mekong Delta is still very modest compared to other countries in the region such as Thailand, China, the Philippines... Particularly, productivity and export markets are instable; the quantity and quality of processed products not high; the fruit export turnover not commensurate with the real potential. The cause of this is partly due to the not really effective mechanism for coordinating and cooperating between actors in the region's export organic supply chains.

\subsection{Impact of the supply chain operation management}

The regression results show that the operational management (variable namely OPM in Table 3 ) has a significant and positive impact on the performance of the export organic vegetable and fruit supply chain at confidence level of $99 \%$ with B-value $=$ 0.205 ; Sig. $=0.000$. So, the hypothesis 8 is also validated. The more effective the operation management of the organic supply chain, the higher the performance of export organic vegetable and fruit supply chain. Some researchers have also indicated similar findings about the relationship between operational management with the performance of the export organic fruit and vegetable supply chain (Ivanov et al., 2018; Lambert and Cooper, 2000).

In fact, the export organic vegetable and fruit supply chains in Vietnam have paid more attention to the chain operation management, including: logistics, warehouse management, shipping optimization, procurement optimization, inventory management, cross-connection design, intermodal terminal design... The proper operation of the supply chain of the organic fruits and vegetables for export has brought many advantages to the actors, typically reducing product loss in transportation and storage; increasing profits; improving advanced technology and engineering, capital and knowledge among the chain partners; better information about product flow, market and technology; better control of the safety and quality of organic produce; large investments and risks are shared among the chain partners. By adopting VietGAP (Vietnamese Good Agricultural Practices), the quality and operation process of exporting organic fruits and vegetables are strictly controlled for gaining trust and reputation in export markets.

\subsection{Impact of the supply chain marketing strategy}

According to the regression results, the marketing strategy (variable namely MSG in Table 3) has a significant and positive impact on the performance of the export organic vegetable and fruit supply chain at confidence level of $99 \%$ with B-value = 0.136 ; Sig. $=0.000$. So, the hypothesis 9 is validated. The better organic supply chain marketing strategy, the higher the performance of the export organic vegetable and fruit supply chain; that is similar to the previous findings (Agi and Yan, 2020; Green et al., 2012; Lambert and Cooper, 2000).

In fact, the considerable attention is being paid to the marketing strategy of the export organic fruit and vegetable supply chains in developing countries like Vietnam. These countries have chosen one of three types of the marketing strategy feasible in the long term to apply to the export agricultural supply chain, including: differentiation, centralization and cost management strategy. These strategies have brought a lot of benefits to supply chains, especially enabling chains to accurately identify a specific target market and implement marketing measures aimed at that market, to contribute to improving the chain performance. 


\section{Conclusion}

This paper analyzed the determinants of export organic supply chain by an empirical study on a sample of 308 actors of vegetable and fruit supply chains in Vietnam. The research findings highlighted seven activities that have a significant and positive impacts on the export organic supply chain performance, including: (i) need-satisfying ability, (ii) relationship management, (iii) information management, (iv) quality management, (v) coordination and cooperation mechanisms, (vi) operation management, and (vii) marketing strategy. The differentiated segmentation strategy and cost strategy do not influence the performance of the export organic fruit and vegetable supply chain in Vietnam.

Our research contributes in the literature on the export organic supply chain, by focusing on the lack relating to the performance determinants. Specifically, we identified the key success factors of supply chain in general, and the agricultural ones in particular; then we applied in the case of export organic supply chain by testing their impacts in our empirical study in Vietnam. In managerial plan, our findings should be considered, particularly in developing countries, by firms - actors or members of export organic supply chain, and also by policy-makers in their development planning of export organic agricultural production. This study has some limitations such as research field limited in a developing country of Vietnam, and also only focusing on the export vegetables and fruits. Another limit concerns the number of 92 export supply chains, it means that some of 308 actors participated in the survey are in the same supply chain. These limits can be considered as interesting research perspectives, whereby empirical studies will focus on several developing and least developed countries with a survey of leading actors of export organic supply chain.

\section{References}

Agi, M. A. N., Yan, X., 2020. Greening products in a supply chain under market segmentation and different channel power structures. International Journal of Production Economics 223, 107523.

Albert, T. C., 2003. Need-based segmentation and customized communication strategies in a complex-commodity industry: A supply chain study. Industrial Marketing Management 32, 281-290.

Augustine, P., Guillaume, M., 2021. Resilience of French organic dairy cattle farms and supply chains to the Covid-19 pandemic. Agricultural Systems 190, 103082.

Brun, A., Castelli, C., 2008. Supply chain strategy in the fashion industry: Developing a portfolio model depending on product, retail channel and brand. International Journal of Production Economics 116, 169-181.

Chu-Hua, K., Christian, N. M., Lin, C., 2001. The relationship between supply chain quality management practices and organisational performance. International Journal of Quality and Reliability Management 18, 864-872.

Dimitri, C., Oberholtzer, L., 2007. Market-led versus government-facilitated growth: Development of the U.S. and EU organic agricultural sectors, In: Wellson, J. A. (Ed), Organic Agriculture in the US. Nova Science, New York, NY.

Edwardson, W., Santacoloma, P., 2013. Organic supply chains for small farmer income generation in developing countries: Case studies in India, Thailand, Brazil, Hungary and Africa. Food and Agriculture Organization of the United Nations. Available at: http://www.fao.org/docrep/017/i3122e/i3122e.pdf

Food and Agriculture Organization of the United Nations [FAO], World Health Organization [WHO], 2007. Codex Alimentarius - Organically Produced Foods. 3rd ed. WHO, Rome, Italy. Available at: http://www.fao.org/3/a1385e/a1385e00.pdf

Fynes, B., Voss, C., Búrca, S., 2005. The impact of supply chain relationship quality on quality performance. International Journal of Production Economics 96, 339-354.

Green, K. W. Jr., Whitten, D., Inman, R. A., 2012. Aligning marketing strategies throughout the supply chain to enhance performance. Industrial Marketing Management 41, 1008-1018.

Hauser, M., Delve, R., 2007. Turning market-oriented organic agriculture upside down. Rural Development News 1, 24-28.

He, Y., Yin, S., 2020. Cost analysis in global supply chains. Operations Research Letters 48, 658-665.

International Federation of Organic Agriculture Movements [IFOAM], 2008. Definition of organic agriculture. IFOAM General Assembly. Available at: https://www.ifoam.bio/why-organic/organic-landmarks/definition-organic

International Fund for Agricultural Development [IFAD], 2005. Organic Agriculture and Poverty Reduction in Asia: China and India focus: Thematic evaluation. IFAD, Rome, Italy. Available at: https://www.ifad.org/documents/38714182/397368 72/asia.pdf/553e0316-e3a9-414d-b7e7-25f46471cf60

Ivanov, D., Tsipoulanidis, A., Schönberger, J., 2018. Basics of supply chain and operation management, In: Global Supply Chain and Operations Management. Springer, Berlin, Germany. 
Kerdsriseam, C., Suwanmaneepong, S., 2015. Organic agricultural producer strategies in supply chain of sustainable agriculture network, Chachoengsao province, Thailand. Journal of Agricultural Technology 11, 1731-1742.

Koekoek, F. J., Leijdens, M., Rieks, G., 2010. Entering the Organic Export Market: A Practical Guide for Farmers' Organisations. Agromisa Foundation, Wageningen, Netherland.

Lambert, D. M., Cooper, M. C., 2000. Issues in supply chain management. Industrial Marketing Management 29, 65-83.

Lau, H., Shum, P. K. C., Nakandala, D., Fan, Y., Lee, C., 2020. A game theoretic decision model for organic food supplier evaluation in the global supply chains. Journal of Cleaner Production. 242, 118536.

Lo, V. H. Y., Yeung, A., 2006. Managing quality effectively in supply chain: A preliminary study. Supply Chain Management 11, 208-215.

Marks, S., 2019. Asia-Pacific trade and investment report 2019: Navigating non-tariff measures towards sustainable development. Bulletin of Indonesian Economic Studies 56, 127-135.

Mostaghel, R., Oghazi, P., Patel, P. C., Parida, V., Hultman, M., 2019. Marketing and supply chain coordination and intelligence quality: A product innovation performance perspective. Journal of Business Research 101, 597-606.

Padel, S., Lampkin, N., 2007. The development of government support for organic farming in Europe, In: Lockeretz, W. (Ed), Organic Farming: An International History. CABI, Cambridge, MA.

Panpluem, N., Yin, C., 2021. Supply chain characteristics of certified organic rice in Yasothon province, Thailand. STOU Journal of Agriculture 3, 45-54.

Prajogo, D., Olhager, J., 2012. Supply chain integration and performance: The effects of long-term relationships, information technology and sharing, and logistics integration. International Journal of Production Economics 135, 514-522.

$\mathrm{Pu}, \mathrm{X}$., Xu, Z., Huang, R., 2020. Entry mode selection and its impact on the competition between organic and conventional agricultural products. Journal of Cleaner Production 274, 122716.

Robinson, C. J., Malhotra, M. K., 2005. Defining the concept of supply chain quality management and its relevance to academic and industrial practice. International Journal of Production Economics 96, 315-337.

Semos, A. V., 2002. Organic production, organic food and the role of agricultural policy. New Medit 1(4), 54-61.

Stolze, M., Lampkin, N., 2009. Policy for organic farming: Rationale and concepts. Food Policy 34, 237-244.

van der Vorst, J. G. A. J., da Silva, C. A., Trienekens, J. H., 2007. Agro-Industrial Supply Chain Management: Concepts and Applications. Food and Agriculture Organization of the United Nations [FAO], Rome, Italy.

van Roekel, J., Boselie, D. M., 2002. Agri-supply chain management: To stimulate cross-border trade in developing countries and emerging economies. World Bank Paper Cross-Border Agri Supply Chain Management.

Whicker, L., Bernon, M., Templar, S., Mena, C., 2009. Understanding the relationships between time and cost to improve supply chain performance. International Journal of Production Economics 121, 641-650.

Willer, H., Trávníček, J., Meier, C., Schlatter, B., 2021. The world of Organic Agriculture 2021. FiBL \& IFOAM. Available at: https://www.fibl.org/fileadmin/documents/shop/1150-organic-world-2021.pdf

Worstell, J., 2020. Ecological resilience of food systems in response to the COVID-19 crisis. Journal of Agriculture, Food Systems, and Community Development 9, 23-30.

Xu, L., Beamon, B. M., 2006. Supply chain coordination and cooperation mechanisms: An attribute-based approach. Journal of Supply Chain Management 42, 4-12.

Yang, C. C., Lai, P. L., Li, Y., Hsu, Y. Y., 2018. Supply chain key success factors for organic agricultural products: Case study in Taiwan. International Journal of Supply Chain Management 7, 261-270.

Yu, Y., He, Y., 2021. Information disclosure decisions in an organic food supply chain under competition. Journal of Cleaner Production 292, 125976.

Zander, K., Hamm, U., 2010. Consumer preferences for additional ethical attributes of organic food. Food Quality and Preference 21, 495-503. 